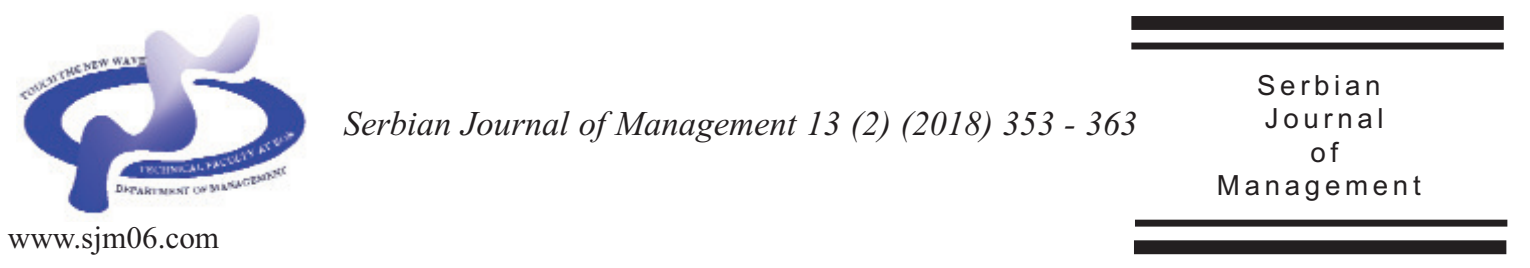

\title{
THE RELATIONSHIP BETWEEN PROFESSIONAL BURNOUT AND SATISFACTION: A CASE STUDY FOR PHYSICAL EDUCATION TEACHERS IN A GREEK URBAN AREA
}

\author{
Evangelia Papasotiriou ${ }^{a}$, Georgios Sidiropoulos ${ }^{a}$, Stamatis Ntanos ${ }^{a}, b^{*}$, \\ Miltiadis Chalikias ${ }^{c}$ and Michalis Skordoulis ${ }^{a, b}$

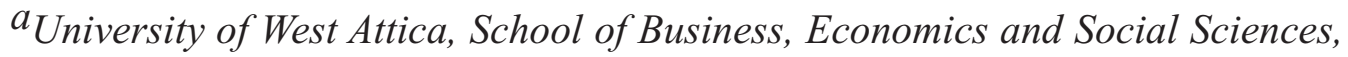 \\ Department of Business Administration, 12244, Aigaleo, Greece

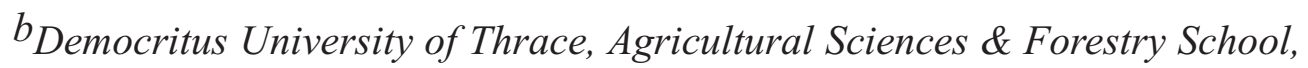 \\ Department of Forestry and Management of the Environment and Natural Resources, \\ 68200, Orestiada, Greece \\ ${ }^{c}$ University of West Attica, School of Business, Economics and Social Sciences, \\ Department of Tourism Management, 12244, Aigaleo, Greece \\ (Received 22 November 2017; accepted 25 April 2018)
}

\begin{abstract}
The aim of the present study is two-fold. Firstly, this research investigates the relationship between the variables of professional burnout and satisfaction among physical education teachers who work in sports organizations of large municipalities in the region of Attica, Greece. Secondly, the relationship between organizational factors and the variables of professional burnout and satisfaction was examined. All the teachers who took part in the survey are occupied in a municipal program called "Sports for all". With the method of random sampling, a total of 100 questionnaires, representing 10\% of the survey population, were filled out by physical education teachers, occupied in 9 municipalities of Attica (Marousi, Kifissia, Heraklion, Metamorfosi-Pefki, N. Ionia, N. Philadelphia, Ilion, Haidari). The analysis reveals that Greek physical education teachers reported low levels of professional burnout and high levels of professional satisfaction. Moreover the results confirm the existence of a relationship between organizational factors, professional burnout and satisfaction.
\end{abstract}

Keywords:burnout, professional satisfaction, physical education teachers, maslach burnout inventory, role conflict, role clarity

\section{INTRODUCTION}

The concept of burnout has received much attention during recent years. Many psychologists, sociologists, management and organizational experts consider that burnout has important implications on the individual, the organization and also on the economy and production. A number of researchers have concluded that professional satisfaction

\footnotetext{
* Corresponding author: sdanos@ath.forthnet.gr
}

DOI: $10.5937 /$ sjm13-15801 
is directly linked to professional burnout. More specifically, low level of professional burnout is correlated or even can be predicted by high level of professional satisfaction (Platsidou \& Agaliotis, 2008; Platsidou, 2010; Chalikias, 2013; Chalikias et al., 2016; Tsitmideli et al., 2016; Zapantis et al., 2017). The purpose of this study was to investigate the relationship between professional burnout and satisfaction for the case of physical education teachers working in sports programs organized by municipal authorities. The role of local authorities in the provision of recreational and social services is important, in order to satisfy the public interest (Torkildsen, 1999). Generally, local authorities play an important role for establishing close relationships because of their proximity to the population. The municipalities in Greece have been given extended responsibilities and obligations towards society and the citizen, especially after 2010 with the application of "Kallikratis" program. The existence of a municipal sports organization in the local government states the priority which is given by the state to the municipal authority for citizens' workout in the area of Athens, Greece (Afthinos, 2001). Concerning the role of physical education teachers in the municipal programs, they are a part of the municipality human resources that can offer very good services to citizens who exercise. On the other hand, they can promote the development of sports organizations that affect positively the economic sector (Nikolaidou et al., 2014).

\section{LITERATURE REVIEW}

For many years burnout is considered to be a critical business issue that affects job satisfaction. Several authors have attempted to define burnout. In the field of psychology, burnout was first used by Bradley (1969) to describe a phenomenon that mostly occurs to healthcare professionals. Freudenberger (1974) defined burnout as the inability for job performance or the exhaustion caused by excessive occupational demands of energy, strength or resources. In 1980, Cherniss described professional burnout as "the disease of over commitment" (Rogers \& Dodson, 1988). There are many studies that have attempted to define burnout, but the most widely accepted definition has been proposed by Maslach \& Jackson (1981): "Burnout is a syndrome of emotional exhaustion and cynicism that occurs frequently among individuals who do 'people-work' of some kind". Numerous studies have argued that teaching is a stressful occupation (Bachkirova, 2005; Blase, 1986; Claxton, 1989; De Nobile \& McCormick, 2005; Kyriacou, 2001). Several studies that have been carried out conclude that professional burnout is the cause of low job satisfaction rather than the opposite (Burke et al., 1984). Locke (1976) defined job satisfaction as "a pleasurable or positive emotional state resulting from the appraisal of one's job or job experiences". Professional satisfaction is directly related to personal life and physical health of an employee (Balzer et al., 1990). Various researches have clearly shown that the most important factors that adversely affect employee's mental health are those of "role clarity" and "role conflict" during their professional life. Role clarity problems occur when an employee is uncertain for the role of his job, the requirements, the way to success and what the other expects from him (Kantas, 1995; Koustelios \& Kousteliou, 1998; Koustelios et al., 2004). Many researchers have confirmed the view that role clarity has the 
highest impact on professional satisfaction as well as the exhaustion of employees. The importance of teachers' clear role towards students' satisfaction and promotion of environmental sensitivity has been pointed out in a recent study for Greek secondary education students (Ntanos et al., 2018). Role conflict occurs when an employee interacts with different people or diverse groups of people (e.g. colleagues, friends, family) who have conflicting expectations from his behavior (Koustelios \& Kousteliou, 1998; Pettinger, 1996). Low et al. (2001) argued that both role conflict and role clarity are important factors that are associated with professional burnout. Several studies have concluded that both role conflict and clarity are negatively related to job satisfaction (Jackson \& Schuller's, 1985; Behrman \& Perreult, 1984).

\section{RESEARCH METHODOLOGY}

For data collection purposes, a survey was conducted in physical education teachers working in Kallikratian Municipalities in the Attica region (Marousi, Kifissia, Heraklion, Metamorfosi-Pefki, N. Ionia, N. Philadelphia, Ilion, Haidari). Sample size was determined on the basis of the total population of physical education teachers. By obtaining data for the total population of 1000 teachers from the Attica municipal authority, a percentage of $10 \%$ was selected by the method of random sampling. Approximately 100 questionnaires were filled out during personal interviews. The questionnaire consists of 24 questions, divided into three sections and responses are based on the 5-point Likert scale, ranging from 1 (strongly agree) to 5 (strongly disagree). Many studies have used this questionnaire for different professions on private and public sector workers in Greece, such as librarians (Togia et al., 2004) and teachers (Koustelios, 2001), confirming its acceptable reliability, validity and the proposed structure. Section A of the questionnaire consisted of several questions probing for teacher's professional satisfaction. For the measurement of Section A, the Employee Satisfaction Inventory (ESI) of Koustelios \& Bagiatis (1997) was used. In order to evaluate the level of professional burnout of physical education teachers, the Maslach Burnout Inventory (MBI) was used (Maslach \& Jackson, 1981, 1986) in section B. Moreover, Role Conflict and Role Ambiguity Scale were used (Rizzo, et al., 1970) in section $C$ of the questionnaire. In the analysis, three research hypotheses have been set for the investigation of the relationship between the variables of professional satisfaction, burnout, role conflict and clarity. The statistical analysis has been carried out by using SPSS v.18 statistical software. More specifically, the statistical analysis methods include Descriptive analysis, Cronbach's alpha, Kaiser-Meyer-Olkin (KMO) test, Bartlett's test of sphericity, Pearson correlation coefficient and stepwise linear regression models.

\section{RESULTS}

Sample demographics are summarized in Table 1.

Initially, the overall reliability of the questionnaire was tested (in all 4 sections of the questionnaire) and Cronbach's alpha index was found to be high (0.855), (Cronbach, 1951). Reliability analysis was also separately performed for each section of 
Table 1. Demographic data of the sample

\begin{tabular}{llrr}
\hline Variable & Demographics & Frequency & Percent \\
\hline \multirow{2}{*}{ Gender } & Male & 50 & 53.8 \\
& Female & 43 & 46.2 \\
& Single/Not married & 25 & 26.9 \\
Marital status & Married & 64 & 68.8 \\
& Divorced/Separated & 3 & 3.2 \\
& Widowed & 1 & 1.1 \\
\multirow{2}{*}{ Employment Contract } & Fixed Term Contract & 5 & 5.5 \\
& Indefinite Duration & 30 & 33 \\
\multirow{2}{*}{ Managerial Duties } & Hourly-Paid & 56 & 61.5 \\
& Yes & 9 & 9.9 \\
& No & 82 & 90.1 \\
\hline
\end{tabular}

the questionnaire. More specifically: 95\% level of confidence (Sig. $=0.000<$ Section's A reliability index (Professional Satisfaction) is 0.853 , Section's B reliability (Professional Burnout) is 0.849, Section's C reliability (Role Clarity) is 0.855 and Section's D reliability (Role Conflict) is 0.774. KMO and Bartlett's Test of Sphericity also gave satisfying results $(\mathrm{KMO}=0.783$; Sig. $=.000)$.

Table 2 presents all the hypotheses that will be examined.

For the first hypothesis, as it can be seen from Table 3, burnout has a negative correlation with role clarity (correlation coefficient $=-0.381$ ) and a positive correlation with role conflict (correlation coefficient $=0.440$ ). All correlations were found to be statistically significant at the 0.05). Therefore, $\mathrm{H}_{1.1}$ is confirmed as it is presented on Table 2.

Concerning the second hypothesis, based on the results of Table 4, a positive correlation was observed between professional satisfaction and role clarity $(0.272$ or $27.2 \%)$ and a negative correlation with role conflict respectively $(-0.28$ or $28 \%$ ). Both correlations were found to be statistically significant at the $99 \%$ level of confidence. Therefore $\mathrm{H}_{2.1}$ was confirmed as it is presented on Table 2 .

In order to test the third research hypothesis, Pearson's correlation test was applied to examine the relationship between the variables of professional satisfaction and burnout which has three interrelated

Table 2. Research hypotheses

\begin{tabular}{|c|c|}
\hline $\begin{array}{l}1^{\text {st }} \text { Research } \\
\text { Hypothesis }\end{array}$ & $\begin{array}{l}\mathrm{H}_{1.1} \text { : There is a significant relationship between professional burnout } \\
\text { and organizational factors (role clarity and role conflict). } \\
\mathbf{H}_{1.0} \text { : There isn't a significant relationship between professional } \\
\text { burnout and organizational factors (role clarity and role conflict). }\end{array}$ \\
\hline $\begin{array}{c}2^{\text {nd }} \text { Research } \\
\text { Hypothesis }\end{array}$ & $\begin{array}{l}\mathrm{H}_{2.1} \text { : There is a significant relationship between professional satisfaction } \\
\text { and organizational factors (role clarity and role conflict). } \\
\mathrm{H}_{2.0} \text { : There isn't a significant relationship between professional satisfaction } \\
\text { and organizational factors (role clarity and role conflict). }\end{array}$ \\
\hline $\begin{array}{c}3^{\text {rd }} \text { Research } \\
\text { Hypothesis }\end{array}$ & $\begin{array}{l}\mathrm{H}_{3.1} \text { : There is a significant relationship between professional satisfaction } \\
\text { and the three dimensions of burnout (emotional exhaustion, personal } \\
\text { accomplishment and depersonalization). } \\
\mathrm{H}_{3.0} \text { : There isn't a significant relationship between professional satisfaction } \\
\text { and the three dimensions of burnout (emotional exhaustion, personal } \\
\text { accomplishment and depersonalization). }\end{array}$ \\
\hline
\end{tabular}


Table 3. Correlation between professional burnout, role clarity and conflict

\begin{tabular}{clrrr}
\hline & & Burnout & Role Clarity & Role Conflict \\
\hline \multirow{2}{*}{ Role Clarity } & Pearson Correlation & $-.381 * *$ & 1 & $-.379 * *$ \\
& Sig. (2-tailed) & .000 & & .000 \\
Role Conflict & Pearson Correlation & $.440 * *$ & $-.379 * *$ & 1 \\
& Sig. (2-tailed) & .000 & .000 & \\
\hline$* *$ Correlation is significant at the 0.01 level (2-tailed). & & &
\end{tabular}

dimensions, as proposed by Maslach (1981). The results in Table $5(\mathrm{r}=-0.446 ; \mathrm{p}<0.01)$ show a moderate negative correlation between emotional exhaustion and professional satisfaction, compatible with the research of Evans \& Fischer (1993).

These results mean that as professional satisfaction increases, emotional exhaustion decreases and the opposite. Also, by looking Sig. (2-tailed) $=0.000$, the correlation is considered statistically significant at the 0.01 level. Also a weak positive correlation $(\mathrm{r}=$
0.176) was found between the dimensions of professional satisfaction and personal accomplishment. This correlation is rejected at $95 \%$, but is accepted at the $90 \%$ level of confidence (Asymp. Sig. $=0.09<0.10$ ). However, the correlation between depersonalization and professional satisfaction hasn't been confirmed (Sig. = $0.894>0.05)$. The analysis of correlations emphasized the influence of the three dimensions of burnout on professional satisfaction. To identify the most effective

Table 4. Correlation between professional satisfaction, role clarity and conflict

\begin{tabular}{llrrr}
\hline & & Satisfaction & Role Clarity & Role Conflict \\
\hline \multirow{5}{*}{ Role Clarity } & Pearson Correlation & $.272 * *$ & 1 & $-.379 * *$ \\
& Sig. (2-tailed) & .007 & & .000 \\
& $\mathrm{~N}$ & 98 & 98 & 98 \\
& Pearson Correlation & $-.280 * *$ & $-.379 * *$ & 1 \\
\multirow{5}{*}{ Role Conflict } & Sig. (2-tailed) & .005 & .000 & \\
& $\mathrm{~N}$ & 98 & 98 & 98 \\
\hline ** Correlation is significant at the 0.01 level (2-tailed). & & &
\end{tabular}

Table 5. Correlation between professional satisfaction and the three dimensions of burnout

\begin{tabular}{|c|c|c|c|c|}
\hline & & $\begin{array}{l}\text { Emotional } \\
\text { Exhaustion }\end{array}$ & $\begin{array}{c}\text { Personal } \\
\text { Accomplishment }\end{array}$ & Depersonalization \\
\hline \multirow{3}{*}{$\begin{array}{l}\text { Emotional } \\
\text { Exhaustion }\end{array}$} & Pearson Correlation & 1 & & \\
\hline & Sig. (2-tailed) & & & \\
\hline & N & $\begin{array}{r}94 \\
-470 * *\end{array}$ & 1 & \\
\hline \multirow{3}{*}{$\begin{array}{c}\text { Personal } \\
\text { Accomplishment }\end{array}$} & Sig. (2-tailed) & ,000 & & \\
\hline & $\mathrm{N}$ & 94 & 94 & \\
\hline & Pearson Correlation &, $533 * *$ &,$- 465 * *$ & 1 \\
\hline \multirow[t]{3}{*}{ Depersonalization } & Sig. (2-tailed) & ,000 &, 000 & \\
\hline & $\mathrm{N}$ & 94 & 94 & 94 \\
\hline & Pearson Correlation &,$- 446 * *$ &, 176 & $-0,14$ \\
\hline \multirow[t]{2}{*}{ Satisfaction } & Sig. (2-tailed) & ,000 & ,091 & ,894 \\
\hline & $\mathrm{N}$ & 94 & 94 & 94 \\
\hline
\end{tabular}


Table 6. Linear Regression Model

\begin{tabular}{ccccc}
\hline \multicolumn{5}{c}{ Model Summary } \\
\hline Model & $\mathrm{R}$ & R Square & Adjusted R Square & $\begin{array}{c}\text { Std. Error of the } \\
\text { Estimate }\end{array}$ \\
\hline $\mathbf{1}$ & $.446 \mathrm{a}$ & .199 & .190 & .42190 \\
$\mathbf{2}$ & $.518 \mathrm{~b}$ & .269 & .253 & .40527 \\
\hline \multicolumn{4}{c}{ 1.Predictors: (Constant), Emotional Exhaustion, 2. Predictors: (Constant), Emotional Exhaustion, } \\
\hline
\end{tabular}

model for estimating the professional satisfaction, a multiple linear regression with the stepwise method was conducted. Multiple linear regression models were developed to estimate professional satisfaction with the variables of emotional exhaustion and depersonalization.

The linear regression analysis results presented in Table 6 show that for the professional satisfaction (dependent variable) two predictive models were statistically significant. The best predictive model is model 2. For the model 2, Adjusted $\mathrm{R}$ Square $=0.253$ (Table 6) and this means that this model explain $25 \%$ of the variance of teachers' professional satisfaction.

The coefficient signs indicated that "emotional exhaustion" was negatively related with "professional satisfaction", while "depersonalization" was positively related with "professional satisfaction". Multifactor linear regression model is described by the equation: $y=a_{0}+a_{1} x_{1}+$ $\mathrm{a}_{2} \mathrm{x}_{2}$.

Table 7. The results of multiple regression analysis regarding the prediction of teachers' professional satisfaction based on the two dimensions of burnout

\begin{tabular}{|c|c|c|c|c|c|c|}
\hline \multicolumn{2}{|r|}{ Model } & \multicolumn{2}{|c|}{$\begin{array}{l}\text { Unstandardized } \\
\text { Coefficients }\end{array}$} & \multirow{2}{*}{$\begin{array}{c}\begin{array}{r}\text { Standardized } \\
\text { Coefficients }\end{array} \\
\text { Beta }\end{array}$} & \multirow[t]{2}{*}{$\mathrm{t}$} & \multirow[t]{2}{*}{ Sig. } \\
\hline & & $\mathrm{B}$ & Std. Error & & & \\
\hline \multirow[t]{3}{*}{1} & (Constant) & 4.269 & .170 & & 25.126 & .000 \\
\hline & Emotional & -389 & .081 & -.446 & -4.776 & .000 \\
\hline & Exhaustion & & & & & \\
\hline \multirow[t]{3}{*}{2} & (Constant) & 4.158 & .168 & & 24.821 & .000 \\
\hline & $\begin{array}{l}\text { Emotional } \\
\text { Exhaustion }\end{array}$ & -534 & .092 & -612 & -5.779 & .000 \\
\hline & Depersonalization & .260 & .088 & .313 & 2.950 & .004 \\
\hline
\end{tabular}

The model of multiple linear regression can be represent as:

Professional Satisfaction $=-0.534 \times$ Emotional Exhaustion $+0.260 \times$ Depersonalization +4.158

where:

$\mathrm{y}=$ Response variable (Professional Satisfaction)

$\mathrm{a}_{0}=$ Constant variable

$\mathrm{a}_{1}=$ Coefficient of first control variable, $\mathrm{x}_{1}$

$a_{2}=$ Coefficient of second control variable, $\mathrm{x}_{2}$

$\mathrm{x}_{1}=$ Controlled variable (Emotional Exhaustion)

$\mathrm{x}_{2}=$ Controlled variable

The resulted model shows that the (Depersonalization) 
estimation of the degree of professional satisfaction can be predicted by using emotional exhaustion and depersonalization (values from 1 to 5 ). It is concluded that $\mathrm{H}_{3.1}$ is only confirmed for the two dimensions of burnout (emotional exhaustion and depersonalization).

\section{CONCLUSIONS}

The above analysis has shown that teachers of physical education have a low degree of burnout and a high level of professional satisfaction, for the case of Attica, Greece. The results are compatible with the literature since other studies also report low burnout levels for the case of Greek teachers (Kantas, 1996; Koustelios \& Kousteliou, 2001; Kokkinos, 2006; Amarantidou \& Koustelios, 2009). Concerning the research hypotheses, a negative correlation was indicated between professional burnout and the two dimensions of professional satisfaction (role clarity and role conflict). More specifically, a decrease in role clarity leads to increased burnout. Also, as role conflict increases, burnout increases respectively. These results are also supported by literature, since similar studies have pointed out that both role conflict and role clarity are important factors that are associated with professional burnout (Low et al., 2001). Also statistical significant correlation was found between two of the organizational factors (role clarity and conflict) and professional satisfaction. More specifically, there is a positive correlation between professional satisfaction and role clarity and a negative correlation between professional satisfaction and role conflict. These findings are consistent with a body of literature supporting that role clarity and conflict are two of the characteristics of organizational environment that adversely affect employee's professional satisfaction (Koustelios \& Kousteliou, 1998; Koustelios et al., 2004; Wood et al., 1998; Rizo et al., 1970). Another research hypothesis investigated the correlation between professional satisfaction and the three dimensions of professional burnout (emotional exhaustion, depersonalization and personal accomplishment. According to the results, Pearson's correlation coefficient between emotional exhaustion and job satisfaction was $-0,446$, which depicts a moderate negative correlation between the two variables. These findings are consistent with various studies estimating a moderate to high correlation between the variables of emotional exhaustion and professional satisfaction in various occupations (Pisanti et al., 2003; Bhana \& Haffejee, 1996; Dolan, 1987; Koeske \& Kirk, 1994; Pines et al., 1980; Evans \& Fischer, 1993). Finally, by using linear regression method it has been concluded that emotional exhaustion and depersonalization ( 2 of the 3 dimensions of burnout according to Maslach) are statistically significant in predicting the individual's degree of professional satisfaction. Therefore, the structure and organization of municipalities in all service sectors should be governed by administrative consistency and supported by scientific committees. One of the priorities of municipal sports programs is the attention to applying management and marketing techniques in order to improve their image, increase public acceptance and improve employee's understanding of the organizational structure since this can be beneficial for all stakeholders as in the case of Greek small private enterprises (Ntanos 
and Ntanos, 2014). The existence of a well organized structured with defined role duties and the provision of information to employees about the organizational structure and strategy should be of high importance in the effort to minimize the burnout syndrome.

\section{References}

Afthinos I. (2001). Organizational Operations \& Structure in Municipal Sports Organizations, 2nd Edition, Athens.

Amarantidou S., \& Koustelios A. (2009). Differences in burnout levels, role clarity and role conflict in Physical Education Teachers, Sports and Recreation Management Magazine, 6 (2), 20-33.

Bachkirova T. (2005). Teacher Stress and
Personal Values: An Exploratory Study, School Psychology International, 26 (3), 340-352.

Balzer W.K., Smith P.C., Kravitch D.A., Lovell S.E., Paul K.B., Reilly B.A., \& Reilly C.E. (1990). User's manual for the Job Descriptive Index (JDI) and the Job in General (JIG) scales, Bowling Green, OH: Bowling Green State University.

Behrman D., \& Perreault W. (1984). A role stress model of the performance and satisfaction of industrial salesperson, Journal of Marketing, 48, 9-21.

Bhana A., \& Haffejee N. (1996). Relation among measures of burnout, job satisfaction and role dynamics for a sample of South African child-care social workers, Psychological Reports, 79, 431-434.

Blasé J., (1986). A qualitative analysis of

\title{
ОДНОС ИЗМЕБУ ПРЕЗАСИЋЕЊА И ЗАДОВОЉСТВА ПОСЛОМ: СТУДИЈА СЛУЧАЈА НАСТАВНИКА ФИЗИЧКОГ ВАСПИТАЫА У УРБАНОЈ ОБЛАСТИ У ГРЧКОЈ
}

\author{
Evangelia Papasotiriou, Georgios Sidiropoulos, Stamatis Ntanos, \\ Miltiadis Chalikias, Michalis Skordoulis
}

\section{Извод}

Ово истраживање је имало два циља. У почетку, истраживање испитује однос између променљивих презасићења на раду и задовољства на раду, међу наставницима физичког васпитања који раде у спортским организацијама великих општина у региону Атике у Грчкој. Друго, испитује се однос између организационих фактора и промењивих презасићење и задовољство на раду. Сви наставници који су учествовали у истраживању су ангажовани у општинском програму под називом "Спорт за све". Методом случајног узорковања прикупњено је укупно 100 упитника које су попунили наставници физичког васпитања запослени у 9 општина Атике (Мароуси, Кифиссиа, Хераклион, Метаморфоси-Пефки, Н. Иониа, Н. Филаделфија, Илион, Хаидари) и представљају 10\% од укупног броје испитиване популације. Анализа показује да грчки наставници физичког имају низак степен презасићења и висок ниво задовољства радом. Штавише, резултати потврђују постојање везе између организационих фактора, презасићења и задовољења посла.

Кључне речи:презасићење, професионално задовољство, наставници физичког васпитања, “Maslach Burnout Inventory", улога конфликта, разумевање делегираних улога 
sources of teacher stress: Consequences for performance, American Educational Research Journal, 23(1), 13-40.

Bradley H.B. (1969). Community-based treatment for young adult offenders, Crime and Delinquency, 15, 359-370.

Burke R.J., Shearer J., \& Desza E., (1984). Burnout among men and women in police work: An examination of the Cherniss model, Journal of Health and Human Resources Administration, 7 (2), 162-188.

Chalikias M., (2013). Research of personnel selection methods in the Greek private bank sector, African Journal of Business Management, 7(26), 2570-2575.

Chalikias M., Drosos D., Skordoulis M., \& Tsotsolas N. (2016). Determinants of customer satisfaction in healthcare industry: the case of the Hellenic Red Cross, International Journal of Electronic Marketing and Retailing, 7 (4), 311-321.

Cherniss C., (1980). Professional burnout in human organization, New York: Preager Publisher.

Claxton G., (1989). Being a teacher: A positive approach to change and stress, London: Cassell.

Cronbach L. J., (1951). Coefficient alpha and the internal structure of tests, Psychometrika, 16(3), 297-334.

Dolan N., (1987). The relationship between burnout and job satisfaction in nurses, Journal of Advanced Nursing, 12, 312.

De Nobile J.J., \& McCormick J., (2005). Job satisfaction and occupational stress in Catholic primary schools, Paper presented at the Annual Conference of the Australian Association for Research in Education, Sydney.

Evans B.K., \& Fischer D.G., (1993). The nature of burnout: $\alpha$ study of the three factor model of burnout in human service and non-human service samples, Journal of Occupational and Organisational Psychology, 66, 29-38.

Freudenberger H., (1974). Staff burnout, Journal of social Issues, 30, 159-165.

Jackson S., \& Schuler R.S., (1985). A meta-analysis and conceptual critique of research on role ambiguity and role conflict in work settings, Organizational Behavior and Human Decision Processes, 36, 17-78.

Kantas A., (1995). OrganizationalIndustrial Psychology, Part 3, Group Processes, Conflict, Growth and Change Culture. Professional Stress. Athens: Ellinika Grammata.

Kantas A., (1996). The Burnout Syndrome in Teachers and Workers in Health and Welfare Professions, Psychology, 3, 7185.

Koeske G.F., \& Kirk S.A., (1994). Measuring the Monday blues: validation of a job satisfaction scale for the human services, Social Work Research, 18, 27-35.

Kokkinos C.M., (2006). Factor structure and psychometric properties of the Maslach Burnout Inventory-Educators Survey among elementary and secondary school teachers in Cyprus, Stress and Health, 22 (1), 25-33.

Koustelios, A. (2001). Personal characteristics and job satisfaction of Greek teachers. TheInternational Journal of Educational Management, 15(7), 354-358.

Koustelios A., \& Bagiatis K., (1997). The employee satisfaction inventory (ESI): Development of a scale to measure satisfaction of Greek employees, Educational and Psychological Measurement, 57, 469-76.

Koustelios A., \& Kousteliou I., (1998). Relations among measures of job satisfaction, role conflict, and role clarity for a sample of Greek teachers, Psychological Reports, 82, 131-136. 
Koustelios A.D., Kousteliou I., (2001). Job satisfaction and burnout in education, Psychology, 8 (1), 30-39.

Koustelios A., Theodorakis N., \& Goulimaris D., (2004). Role clarity, role conflict and job satisfaction among physical education teachers in Greece, The International Journal of Education Review, 11(2), 189-203.

Kyriacou C., (2001). Teacher stress: Directions for future research, Educational Review, 53(1), 28-35.

Locke E.A., (1976). The nature and causes of job satisfaction, in Dunnette, M.D. (Ed.), Handbook of Industrial and Organizational Psychology, Rand McNally, Chicago, 1297-349.

Low G.S., Cravens D.W., Grant K., \& Moncrief W.C., (2001). Antecedents and consequences of salesperson burnout, European Journal of Marketing, 35, 587-614.

Maslach C., \& Jackson S.E., (1981). The measurement of experienced burnout, Journal of Occupational Behaviour, 2, 99113.

Maslach C., \& Jackson S.E., (1986). Manual Maslach Burnout Inventory, Consulting Psychologists Press, Palo Alto (2nd edition), California.

Nikolaidou S., Yfantidou G., Kostas G., \& Gialamas B., (2014). Types of approximation of an organization in Municipal Sports Organizations, Administration of Sports and Recreation, 11 (2), 1-13.

Ntanos A., \& Ntanos S., (2014). The Impact of Marketing Strategy in Small Family Businesses, Strategic Marketing in Fragile Economic Conditions, Chapter 8, 153-166, IGI Global.

Ntanos, S., Kyriakopoulos, G.L., Arabatzis, G., Palios, V., \& Chalikias, M. (2018). Environmental Behavior of
Secondary Education Students: A Case Study at Central Greece, Sustainability, 10, 1663.

Pettinger R., (1996). Introduction to Organizational Behavior, Macmillan: London and Basingstoke.

Pines A., Aronson E., \& Kafry D., (1981). Burnout: From tedium to personal growth, New York: Free Press.

Pisanti R., Gagliardi M.P., Razzino S., \& Bertini M., (2003). Occupational Stress and Wellness among Italian Secondary School Teachers, Psychology and Health, 18 (4), 523-536.

Platsidou M., (2010). Trait Emotional Intelligence of Greek Special Education Teachers in Relation to Burnout and Job Satisfaction, School Psychology International, 31 (1), 60-76.

Platsidou M., \& Agaliotis I. (2008). Burnout, job satisfaction and instructional assignment related sources of stress in Greek special education teachers, International Journal of Disability, Development and Education, 55 (1), 61-76.

Rizzo J., House R., \& Lirzman S., (1970). Role conflict and ambiguity in comlex organizations, Administrative Science Quarterly, 15, 150-163.

Rogers J.C., \& Dodson S.C., (1988). Burnout in occupational therapists, Am. J. Occup. Ther., 42 (12), 787-792.

Togia, A., Koustelios, A. \& Tsigilis, N. (2004). Job satisfaction among Greek librarians. Library and Information Science Research, 26, 373-383.

Torkildsen G., (1999). Leisure and Recreation Management, 4th edition, London: E \& FN Spon.

Tsitmideli G., Skordoulis M., Chalikias M., Sidiropoulos G., \& Papagrigoriou A. (2016). Supervisors and subordinates relationship impact on job satisfaction and efficiency: The case of obstetric clinics in 
Greece, International Journal of Strategic Innovative Marketing, 3(3), 1-12.

Wood, J., Wallace, J., Zeffane, R., Schermerhorn, J.R., Hunt, J.G. \& Osborn, R.N. (1998). Organisational Behavior: An Asia-Pacific Perspective, Wiley, Jacaranda.

Zapantis G., Skordoulis M., Chalikias M., Drosos D., \& Papagrigoriou A., (2017). Measuring the Impact of Burnout on Job Satisfaction and Organizational Commitment, Strategic Innovative Marketing, Springer, Cham, 51-55. 